\title{
Truncation Mutation
}

National Cancer Institute

\section{Source}

National Cancer Institute. Truncation Mutation. NCI Thesaurus. Code C148641.

The mutation of either a splice site or stop codon that leads to a truncated transcript. 